Şahin, C. (2020). Özel yetenekli öğrencilerin kurguladığı yaratıcı yazma çalışmalarında "deus ex machina". Ana Dili Eğitimi Dergisi, 8(2), 611-627.

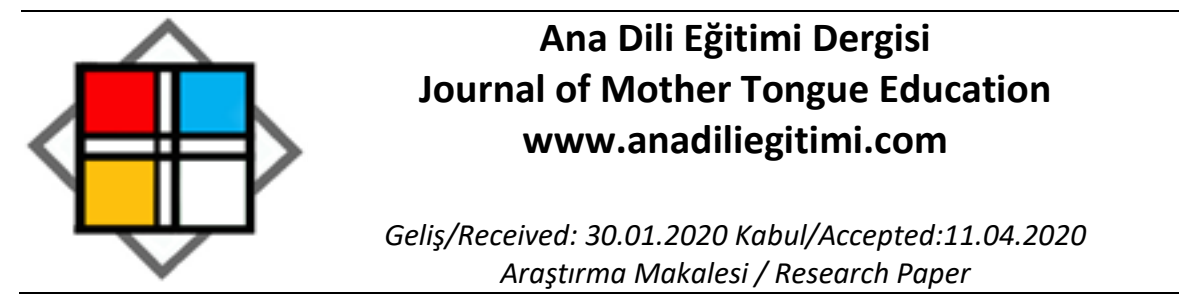

\title{
Özel Yetenekli Öğrencilerin Kurguladığı Yaratıcı Yazma Çalışmalarında “Deus Ex Machina”
}

\author{
Cemil ŞAHIN*
}

\begin{abstract}
Öz
Yaratıcı düşünmenin ve yazma becerisinin kesişim noktası olan yaratıcı yazma, düşüncelerdeki doğruluk ya da standartlaşmadan çok özgünlük, özgürlük ve hayal gücünü vurguladığı için yazma çalışmaları içerisinde farklı bir yere sahiptir. Fakat özgünlük, özgürlük ve hayal gücünün vurgulandığı yaratıcı yazma çalışmaları metinsellik ölçütlerinden muaf çalışmalar değildir. Yaratıcı yazma çalışmalarında kurguyu oluşturan ve kuralları koyan yazarın kendisidir. Fakat yazar bazen kurguyu altüst etmekte ve metin tutarlıığını bozmaktadır. Olayların düğümlendiği bir noktada mantık sınırlarıı zorlayan herhangi bir kişi ya da nesne ortaya çıkmakta ve bir tanrı edasıyla olayları çözmektedir. Bu kurgu hatası "deus ex machina" (makineden çıkan tanrı) olarak adlandırımaktadır. Bu bilgiler ışığında araştırmanın amacı, özel yetenekli öğrencilerin kurguladığı yaratıcı yazma çalışmalarındaki "deus ex machina" unsurlarını ortaya çıkartmaktır. Bu amaş doğrultusunda kırk iki özel yetenekli öğrenci tarafından yazıımış kırk iki yaratıcı yazma örneğ doküman analizi yöntemi ile incelenmiştir. Doküman analizi sonucunda elde edilen bulgulara göre kırk iki (\%100) yaratıı yazma örneğinin on altısında (\%38) "deus ex machina" unsuruna rastlanmıştır.
\end{abstract}

Anahtar Kelimeler: Özel yetenekli öğrenci, yaratııı yazma, deus ex machina.

\begin{abstract}
"Deus Ex Machina" in Creative Writing Examples of Gifted Students
Abstract

Creative writing, which is the intersection of creative thinking and writing skills, has a different place in writing studies because it emphasizes originality, freedom, and imagination rather than accuracy or standardization in thoughts. However, creative writing studies which emphasize originality, freedom and imagination do not exclude textual elements. In creative writing, it is the author who creates the fiction and sets the rules. But the author sometimes overturns the fiction and breaks the rules he sets himself. At a point where events are tied, a person, an object, a machine pushing the limits of logic emerges and solves the events as a god. This fiction error is called as "deus ex machina". In the light of this information, the aim of the research is to reveal the elements of "deus ex machina" in creative writing works of gifted students. Forty-two creative writing examples written by forty-two gifted students were examined for this purpose. Document analysis one of the qualitative research methods was administered on the data. Findings of the study indicated that "deus ex machina" was found in sixteen (38\%) of the fortytwo $(100 \%)$ creative writing samples.
\end{abstract}

Keywords: Gifted student, creative writing, deus ex machina.

\section{Giriş}

Bilgiye ulaşmanın kolaylaştığı iletişim çağında, bilgiyi kullanma ön plana çıkarken bireylerin toplum içerisinde mutlu bir yaşam sürdürebilmeleri için temel iletişim becerilerinin geliştirilmesine intiyaç duyulmaktadır. Temel eğitim (1-8. sınıflar) Türkçe derslerinde, Türkçe Öğretim Programı'nda (MEB, 2019a) belirtilen kazanımlar ve temel ilkeler doğrultusunda hazırlanan ders kitapları ve

\footnotetext{
"Doktora Öğrencisi, Gazi Üniversitesi, Eğitim Bilimleri Enstitüsü, Türkçe Eğitimi Anabilim Dalı, Ankara, cemilsahin4040@gmail.com, ORCID: orcid.org/0000-0003-4405-0862.
} 
etkinlikler vasıtası ile öğrencilerin temel iletişim becerileri (dinleme, konuşma, okuma, yazma) geliştirilmeye çalışılmaktadır. Türkçe Öğretim Programı́nın (MEB, 2019a) temelinde ise Avrupa Yeterlilikler Çerçevesi (AYÇ) ile uyumlu bir şekilde hazırlanan Türkiye Yeterlilikler Çerçevesi (TYÇ) ile belirlenen sekiz anahtar yetkinlik bulunmaktadır. Bu anahtar yetkinliklerin ilki "ana dilde iletişim" dir. Ana dilde iletişim, Türkçe Öğretim Programı'nda (MEB, 2019a), "Kavram, düşünce, görüş, duygu ve olguları hem sözlü hem de yazılı olarak ifade etme ve yorumlama (dinleme, konuşma, okuma ve yazma); eğitim ve öğretim, iş yeri, ev ve eğlence gibi her türlü sosyal ve kültürel bağlamda uygun ve yaratıı bir şekilde dilsel etkileşimde bulunmak." olarak tanımlanmıştır. Bu tanımdan hareketle Türkçe Öğretim Programı'nın (MEB, 2019a) dilsel etkileşimdeki yaratıcılığı vurguladığını söylemek mümkündür.

TYÇ ile belirlenen sekiz temel yetkinlik tüm dersler için geçerlidir. Fakat bireyin, sistemli ve kurallı bir şekilde dinleme, konuşma, okuma ve yazma becerilerinin geliştirilmesi öncelikle Türkçe dersinden beklenmektedir. Bu beceriler içerisinde yazma son kazanılan dil becerisidir. Yazma, hem bilişsel hem duyuşsal hem de psikomotor bir eylem olması sebebiyle formel eğitimi gerekli kılmaktadır. Yaratıcı düşünmenin ve yazma becerisinin kesişim noktası olan yaratıcı yazma, düşüncelerdeki doğruluk ya da standartlaşmadan çok özgünlük, özgürlük ve hayal gücünü vurguladığı için yazma çalışmaları içerisinde farklı bir yere sahiptir. Fakat yaratıcı yazma ile kusursuz bir ürün ortaya koymak anlaşılmamalıdır. Çünkü üretimsel faaliyetlerde hata kaçınılmazdır. Yaratıcı yazma çalışmalarında, kurguyu oluşturan ve kuralları koyan yazarın kendisidir. Fakat yazar bazen kurguyu altüst etmekte ve kendi koyduğu kuralları bozabilmektedir. Olayların düğümlendiği bir noktada özgünlükten uzak ve mantık sınırlarını zorlayan herhangi bir kişi ya da nesne ortaya çıkmakta ve bir tanrı edasıyla olayları çözmektedir. Oysaki kurgu, Aristoteles'in Poetika (2019) isimli eserindeki "bütün" algısı ile ele alındığında başı, ortası ve sonu olan bir yapıdır. Bu yapıların ardışıklığı, bölümler arası tutarlılı ile sağlanır. Bununla birlikte karmaşık yahut eksik kurgularda okuyucu, zayıf yahut etkisiz bir son ile karşılaşabilmektedir. Burada kastedilen, şaşırtıcı yahut sürpriz içeren bir sondan ziyade, kurgu ile bağdaşmayan bir müdahale ile kurguyu sonlandırmaktır. Özellikle Antik Yunan'daki metinlerde sıklıkla karşılaşılan bu duruma, ortaya çıkış durumundan ötürü "deus ex machina" (makineden çıkan tanrı) adı verilmiştir (Uysal, 2017). Burada Aristoteles'in kastettiği "makine", öyküdeki olay örgüsü sarpa sardığında yazarın problemi çözmek için "gökten zembille inmiş" gibi sahne üzerinden tanrı rolü üstlenmiş bir insanı sahneye indirmek için kullandığı vinçtir. Bu düzeneğe "makineden çıkan tanrı" anlamında Eski Yunanca "apo mêkhanês theos" ya da "theos ek mêkhanês", Latince "deus ex machina" denmiştir. Kaynağı tiyatro sahnesi olan bu terim giderek tüm kurgu eserlerdeki her çeşit zorlama çözüm aracını, inandııı olmayan rastlantıları karşılamak için kullanılmıştır (Şener, 2006). Bu çalışma ile "beşeri bir hazine" olarak değerlendirilmesi gereken ve "iki kere farklı birey" (twice exceptionality) olarak nitelendirilen özel yetenekli bireylerin kurguladığı yaratıcı yazma örneklerindeki "deus ex machina" olarak adlandırılan kurgu hataları tespit edilmiş ve türlerine göre sınıflandırılmıştır.

Tüm bireyler özel ve tek olup kendine özgü bazı yeteneklerle dünyaya gelmektedir. Ancak, bazı insanlar zekâ, yaratıcılık, bilgi üretme ve problem çözme gibi çeşitli özellikler açısından diğerlerine göre üstünlük ve farklılık göstermektedirler. İlgili alanyazında diğer insanlara nazaran bazı özellikleriyle üstün ve farklı olan bireyler "üstün zekâlı", "üstün yetenekli" veya "özel yetenekli" olarak adlandırılmakta ve birçok tanımı yapılmaktadır (Ataman, 2012; Bildiren, 2016; Clark, 2015; Davis, 2013; Levent, 2014; Millî Eğitim Bakanlığı [MEB], 2001, 2007, 2015, 2016, 2019b, 2019c, 2018a, 2018b; Öznacar \& Bildiren, 2016; Renzulli, 1976; Robinson vd. 2014; Sak, 2016a; Özbay, 2013). Bu kavram karmaşık ve çok boyutlu olması sebebiyle, ortak kabul görmüş bir kullanım ve tanıma ulaşılamamaktadır. Çalışmada, Türkiye genelinde tüm özel eğitim faaliyetlerini kapsayan Özel Eğitim Hizmetleri Yönetmeliği'ndeki (MEB, 2018a) kullanım ve tanım esas alınmıştır. İlgili Yönetmelik'te, "özel yetenekli birey" kullanımı benimsenmiş ve "Yaşıtlarına göre daha hızlı öğrenen, yaratıcılık, sanat, liderliğe ilişkin kapasitede önde olan, özel akademik yeteneğe sahip, soyut fikirleri anlayabilen, ilgi alanlarında bağımsız hareket etmeyi seven ve yüksek düzeyde performans gösteren birey." olarak tanımlanmıştır. Fakat yapılan alıntılarda yazarların kullanımlarına sadık kalınmıştır. Özellikle akademik alanda "üstün yetenekli" uygulamada ise "özel yetenekli" kavramlarının kullanıldığı görülmüştür. 
Türkiye'de kamu politikaları gereği üstün yetenekli öğrenciler normal gelişim gösteren akranları ile öğrenimlerine devam etmektedir. Bu öğrencilere okul içinde (destek eğitim odası) ya da okul dışında (Bilim ve Sanat Merkezleri) farklı destekler sunulmaktadır (Çitil \& Ataman, 2018). Fakat bu bireyler için farklı okullar ya da aynı okul içerisinde farklı sınıflar bulunmamaktadır. Kullandıkları ders kitapları ve diğer eğitim materyalleri farklıık göstermemektedir. Hatta birçok özel yetenekli birey, öğrenme ve düşünme becerileri, ilgi alanları, öğrenme güdüleri, yenilikçi fikir ve merakları ile eğitim sürecinde akranlarından farklılaşmakta, sınıflarda "disiplin unsuru" olarak görülmekte ve hatta "normal olmaya" zorlanmaktadırlar (Borland, 2005; Hotaman \& Yüksel Şahin, 2009). Enç (2005) ise özel eğitim alanı içerisinde en az ilgi çeken ve yatırım sağlanan alanın "üstün beyin gücünün eğitimi" olduğunu belirtmiştir. İnsanlığın çağdaş uygarlık düzeyine erişmesinde katkısı eşsiz olan özel yetenekli bireylerin eğitimi, üzerinde en az durulan özel eğitim dallardan birisi olagelmiştir. Özel yetenekli bireyler kendilerine uygun ortamlarda, zenginleştirilmiş ve hızlandırılmış etkinliklerle eğitimlerine devam edemediklerinde mutsuz, huzursuz olabilmektedirler. Ayrıca bu bireyler, gelişimlerine müsait bir zemin sağlanmadığında yeteneklerinin körelmesiyle de karşılaşabilmektedirler. Clark'ın (2015) da belirttiği gibi sabit bir zekâ ya da yaratıcılıktan söz edilemez. Çünkü zekâ ve yaratıcılık uygun ortam ve şartlar altında geliştirilebilir bir yetenektir. Bundan dolayı tüm bireylere eğitim intiyaçları doğrultusunda öğrenme deneyimleri sunulması önem arz etmektedir.

Torrance (1986) yaratıcılığı özgün bir ürün üretme yeteneği, bazen de zenginleştirme olarak tanımlar. Zweig (1949) için yaratıcılık, zamanı aşmak ve tabiat kanunlarını yıkmak anlamına gelmektedir. Bayındır (2013) yaratıcılığı, maksatlı bir şekilde, olmayan bir şeyi hayal edebilme, bir şeyi herkesten farklı yollarla yapabilme ve yeni fikirler geliştirebilme yeteneği olarak tanımlar ve yaratıcılığın herkesin gördüğü şeyi görmek ancak farklı şeyler düşünmek olduğunu ifade eder. Rowe (2007) yaratıcılığın dünyaca ünlü bir başyapıt üretmek kadar görkemli bir şey olabileceği gibi sıradan bir problemin çözümünü bilmek gibi basit bir şey de olabileceğini belirtir. Sak'a (2016b) göre yaratıclık yeni ve uygun ürünler ortaya koyabilmektir. Renzulli (1992) yaratıcılığı, ortaya bir ürün koymayı gerektiren yaratıcı süreç olarak tanımlar. Clark (2015) ise yaratıcılığı çok özel bir durum, tutum veya neredeyse tüm tanımlara meydan okuyan bir varoluş mücadelesi olarak tanımlar. Bu tanımlardan hareketle yaratıcılı̆ıın yeni, uygun, özgün bir ürün üretme; mevcut bir ürünü zenginleştirme, zamanın sınırlarını aşma, tabiatın kanunlarını yıkma, olmayan bir şeyi hayal edebilme, bir şeyi herkesten farklı bir yol ile yapabilme, yeni fikirler geliştirebilme ve varoluş mücadelesi gibi özellikleri vurguladığını söylemek mümkündür. Bir sincap aynı ağaca bir günde belki yüzlerce kez inip çıkar fakat hiçbir zaman bu iniş çıkışları daha farklı bir şekilde yapmayı düşünmez. Aynı şekilde nehirdeki timsah daha hızlı yüzebilmek için farklı bir arayışa girmez. Arıların bal petekleri hep altıgendir. Çünkü Mutlak Varlık'ın yarattığı türler içerisinde izafî yaratıcılığa sahip olan insandır ve yaratıcılık sayesinde içinde yaşadığı toplumu şekillendirir, değiştirir ve yeniden üretir. Zaten insanın içinde yaşadığı toplum, başlı başına bir yaratıcılık eseridir.

Bir öğrencinin uzaylı varlıkları çizmesi, uzaylıların geldiği gezegeni çizmesi, Mars'taki yaşamı anlatması yahut bunu yazması, hayalindeki kütüphaneyi yazması birer yaratıcılık örneğidir. Yazı, icadından bu yana insanoğlunun yaratıcılığına yeni boyutlar kazandırmıştır. Yazı sadece iletişim vasıtası olmakla kalmamış yazı sayesinde kalıcı olma yolunda önemli adımlar atan insanoğlu bunu bir sanata dönüştürmüştür. Uysal ve Fincan'a (2016) göre bu durum yarına kalma isteği anlamına gelmektedir. Illkel duvar karalamalarından en seçkin edebî eserlere dek "Ben buradaydım!" deme isteğinin nedenidir. Yaratıcı yazma süreç odaklı bir yazma faaliyetidir, bu yönüyle sonuç odaklı yazmadan ayrılır. Çünkü yaratıcı yazmada düşüncedeki doğruluktan, ifadelerdeki standartlardan çok hayal gücü ve özgünlük öne çıkar. Ayrıca yaratıcı yazmada duyguların rahatlıkla ifade edilmesi, düşüncelerin hata yapma endişesi olmaksızın yazıya dökülmesi ve daha önemlisi hoşlanarak haz duyarak yazmak söz konusudur. Temizkan'ın (2010) da belirttiği gibi yaratıcı yazılarla öğrenciler sıkıcı, kendini tekrarlayan, monoton yazılar yazmak yerine özgün, akıcı, ilgi çekici bir şekilde duygu ve düşüncelerini ortaya koymaktadır.

Birçok araştırmacı üstün zekâ ile yaratıcılık arasında önemli bir ilişki olduğunu öne sürmüştür. Stenberg ve Grigorenko (2011) yaratıcılık ve üstün zekâlılık arasında çok önemli bir ilişkiye dikkat çekmişler ve yaratıcılığın üstün zekâlı bireyler için çok önemli olduğunu, üstün zekâlı bireylerin 
başkalarını etkileyecek fikirleri, yaratıcılık sayesinde üretebildiklerini belirtmişlerdir. Renzulli (1978, 2005) ise Üçlü Halka (Çember) Kuramı́nda yaratıcılı̆ı̆ı üstün zekâ için gerekli bir halka olduğunu ileri sürmüştür. Gardner (1993) ise yaratıcılığın, kendisi tarafından önerilen yedi -şu an sekiz- zekâ türünün hepsinin bir parçası olduğu varsayımında bulunmuştur. Ayrıca Geake ve Dodson (2005), üstün zekâlı deneklerin, hücresel ve nörogliyal sistemlerin yoğunluğuna iliş̧in yapılan tüm ölçümlerde, üstün zekâlı olmayan yaşıtlarını ikiye katladığını tespit etmişlerdir. Araştırmacılar bu durumu, üstün zekâlı kişilerin yüksek düzeyde yaratıcı zekâ potansiyeline sahip olmasının nedeni olarak da düşünmektedirler. Conklin ve Frei (2016) akademik başarının tek başına zekânın ya da yaratıcılığın tanımı olamayacağını, bazı öğrencilerin derslerde oldukça yetersiz puanlar alırken tahmin edilmeyen ve fark edilmeyen bazı alanlarda farklı ve yaratıcı özelliklere sahip olabileceklerini belirtmişlerdir. Yaratıcılık ve zekâ arasındaki ilişki genel olarak "Eşik Kuramı" ile açıklanmaya çalışılmıştır (Barron, 1963; Getzels \& Jackson, 1962; Torrance, 1962). Eşik Kuramı'na göre bireyin yaratıcı olması için belli bir zekâ düzeyine sahip olması gerekmektedir. Yani bireyin zekâ düzeyi yaratıcılık için gerekli olan eşik değerini geçmelidir. Yapılan bu araştırmalarda eşik değeri 120 IQ (zekâ düzeyi [ZD]) olarak kabul görmüştür. Eşik kuramını test etmek amacıyla daha sonra yürütülen araştırmalarda (Barron, 1969; MacKinnon, 1978) 120 IQ puanına kadar zekâ ve yaratıcılık arasında pozitif doğrusal bir ilişki bulunmuştur. Diğer deyişle zekâ puanı arttıkça yaratıcılık da artmıştır. Ancak 120 IQ puanından sonra zekâ ve yaratıcılık arasındaki ilişki kaybolmuştur. Bu sonuçtan hareketle çok yüksek IQ puanına sahip bireylerin yaratıcı olamayabilecekleri, fakat ortalama IQ puanına sahip bireylerin yaratıcı olabilecekleri sonucuna ulaşılabilmektedir. Bugün dahi "Yaratıcılık zekâyı kapsar mı?", "Zekâ yaratıcııı̆ı kapsar mı?", "Zekâ ve yaratıcılık aynı şey midir?", "Zekâ ve yaratıcılık arasında nasıl bir ilişki vardır?" soruları güncel ve önemli sorular olarak karşımızda durmaktadır. Gerek Türkiye'de gerekse Dünya'da üstün zekâlı, üstün yetenekli ya da özel yetenekli olarak adlandırılan bireylerden daha yaratıcı olmaları beklenmektedir. Türkçe dersi özelinde ise özel yetenekli öğrencilerin daha yaratıcı konuşabilmeleri ve yazabilmeleri beklenmektedir. Çünkü konuşma ve yazma becerileri ile yaratıcılık kavramlarının keşişim noktası Türkçe dersidir.

"Deus ex machina" Yunan ve Roma tiyatrosunda, bir sahnedeki problemi çözmek ya da kahramanı zor bir durumdan kurtarmak için sahne makineleri tarafından indirilmiş bir tanrı; karmaşık bir durumu veya bir komployu çözmek için kurgu veya drama çalışmasıyla aniden ortaya çıkan beklenmedik, yapay veya imkânsız bir karakter, cihaz veya olay; bir zorluk için ani ve beklenmedik bir çözüm sağlayan kişi veya olay olarak tanımlanmaktadır. Tiyatro Terimleri Sözlüğü'nde (1966) ise “deus ex machina"nın oyunların sonunda, ortadaki sorunu çözmek için gökten inmiş duygusunu sağlayacak bir tanrıyı temsil eden oyuncu olduğu ve bu terimin daha sonraları -ve bugün- olayların akışına, gelişmesine dayanmayan, tepeden inme, inandırıcı olmayan çözümler için kullanılmaya başlandığı belirtilmiştir. Uysal (2017) ise "deus ex machina" kavramını, çözümü zor bir problemin beklenmedik ve ani bir biçimde gelen bir tanrı tarafından beklenmedik biçimde çözülmesine verilen isim olarak açıklamış ve olay örgüsü karmaşık ve içinden çıkılamaz bir hâle geldiğinde bir çözüm olarak kullanılan bu müdahalenin, inandırıcılıktan uzak ve zorlama olabildiğini belirtmiştir. Şener (2006) ise "deus ex machina"nın, teknik bir terim olarak tanrı rolündeki aktör/kahraman anlamına geldiğini ve özellikle Yunan tiyatrosunda amaçlanan sonuç elde edilemeyince sahneye bir tanrı oyuncunun çıktığını, onun buyruğu ile istenen sonucun sağlandığını belirtmiştir. Aristoteles'in, Poetika (2019) isimli eserinde ise bir "deus ex machina"nın olaylara müdahale etmesinin ve olayları tanrısal bir şekilde çözmesinin kurgu ile bağdaşmadığı vurgulanmıştır. Çünkü sonuç, kendinden önceki olayların zorunlu ya da olası sonucu olacak şekilde öykünün kendisinden doğmalıdır. Aristoteles'e göre karakterlerin de temel özelliklerinden birisi tutarlılıktır. Karakterler yaptıkları tercihlerde, zorunluluk ve olasılık kurallarına uymak zorundadır. Olayların gelişiminde bir eylemi; o âna kadarki eylemlerin gerektirdiği veya olasılık dâhiline soktuğu olaylardan biri takip etmelidir. Karakterlerin tercihi de bu koşullarla ya da bilinen farklı kişisel özelliklerle açıklanabilir olmalıdır. Öykünün finali için de aynı şey geçerlidir. Aristoteles bu nedenle "deus ex machina”ya karşı çıkar. Final, eylemlerin içinde yer almayan dış bir güçten değil var olagelen eylemlerin içinden çıkmalıdır (Sezgin, 2009). Bunun için de yazarın fikirlerini, belli bir plan dâhilinde tutarlı bir mantık sırasıyla vermesi gereklidir (Can, 2012). Abrams (1999), Charles Dickens'in Oliver Twist isimli eserinde dahi dikkat çekici "deus ex machina" 
unsurunun bulunduğunu belirtmiştir. Burada Charles Dickens'in Oliver Twist isimli eserindeki dikkat çeken ve yerli, yabancı birçok araştırmada adı geçen "deus ex machina"ya değinmek, bu kavramı somutlaştırmak ve anlaşııılığını artırmak için uygun olacaktır.

“...Oliver Twist, annesini doğarken kaybetmiş, babasını hiç tanımamış, ailesiz ve evsiz bir çocuktur. Hırsızlık yapan bir çete içerisindedir. Arkadaşları, Jack Davkins ve Çarli Beeyts ile hırsızık yapmaktadır. Bir kitapçının önünde kitap okuyan yaşlı adamın para dolu mendili çalınacaktır. Kitap okuyan yaşlı adamın mendili Jack Davkins tarafından ustaca çalınır. Jack Davkins mendili Çarli Beeyts'e verir ve kaçmaya başlarlar. Bu olay birkaç saniyede olup bitmiştir. Fakat yaşlı adam, mendilinin cebinde olmadığını fark eder ve bağırmaya başlar. "Imdat, hırsız var!" Bu çağrı üzerine Oliver Twist ve arkadaşlarını içlerinde bir de polisin olduğu kalabalık bir grup yakalamaya çalışır. Oliver Twist yere düşer ve biraz hırpalanır. Polis, Oliver Twist'i yakalar. Bu esnada kitapçı, "Yaşlı adamın mendilini bu çocuk çalmadı." der. Polis, Oliver Twist'i serbest bırakır. Mendili çalınan yaşlı adam Oliver Twist'e acır ve onu evine götürür. Oliver Twist'in yaralarını sarar ve bakımını üstlenir. Evin duvarında Oliver Twist'e çok benzeyen bir kadının resmi vardır. Resimdeki soylu kadın Oliver Twist'in annesidir. Oliver Twist'i evine götüren yaşlı adam yani Bay Brownlaw, Olivet Twist'in babası Edvin Leeford'un çok yakın arkadaşıdır. Oliver Twist'in annesi Agnes Fleming'i de çok iyi tanımaktadır. Ayrıca Oliver Twist'in gerçek adının Edvard Leeford olduğunu da bilmektedir (Dickens, 2014)."

Bu eserde, kurguya ani ve beklenmedik bir şekilde dâhil olan hırsızlık mağduru yaşı adam, düğümü mantık sınırlarını zorlayan, yapay veya imkânsız bir karakter olarak çözüme kavuşturmuştur. Kurguda, Bay Brownlaw bir kitapçının önünde kitabını okumaktadır. Hırsızlık çetesi tesadüfen bu adamın para dolu mendilini çalmaya karar verir ve çalar. Bu esnada, olay yerinde tesadüfen bir de polis vardır. Kitapçı tesadüfen Oliver Twist'in para dolu mendili çalmadığını görür. Bay Brownlav, tesadüfen tanıdığı ve daha önce hiç görmediği Oliver Twist'i evine götürür. Evin duvarında tesadüfen Oliver Twist'e çok benzeyen bir kadın resmi vardır. Kimsesiz bir çocuk olan Oliver Twist'in karşııına tesadüfen çıkan bu adam, ani ve beklenmedik şekilde kurguya dâhil olmuş ve tüm soru işaretlerini çözüme kavuşturmuştur. Oysa sonuç, Aristoteles'in (2019) de belirtildiği gibi kendinden önceki olayların olası ya da zorunlu sonucu olacak şekilde öykünün kendisinden doğmalıdır, tesadüfler zinciri ile değil. Yaratıcı yazma çalışmaları bireyin kendine has yazma stilini geliştirmeye dönük özgün erişilerdir. Fakat yaratıcı yazma çalışmaları metinsellik ölçütlerinden muaf çalışmalar değildir. Bundan dolayı zorlama ve olağanüstü çözümler (deus ex machina) kurguyu bozacak nitelikte olmamalıdır.

Bu bilgiler ışığında araştırmanın amacı, özel yetenekli öğrencilerin kurguladığı yaratıcı yazma çalışmalarındaki "deus ex machina" unsurlarını ortaya çıkartmaktır. Bu amaca yönelik daha ayrıntılı bulgular ortaya koyabilmek için aşağıdaki alt problemlere cevaplar aranmıştır:

1) Özel yetenekli öğrenciler kurguladıkları yaratıcı yazma çalışmalarında "deus ex machina" unsurlarına yer vermekte midir?

2) Özel yetenekli öğrencilerin kurguladığı yaratıcı yazma çalışmalarında yer alan "deus ex machina" unsurları hangi varlık ya da şahıs ile sembolize edilmiştir?

Bu amaç ve alt problemler doğrultusunda TR Dizin, YÖK Ulusal Tez Merkezi, DergiPark Akademik, YÖK Akademik ve Millî Kütüphane veri tabanlarında "özel yetenekli birey", "yaratıcı yazma" ve "deus ex machina" anahtar kelimeleriyle 04.11.2019 tarihinde yapılan taramada "özel yetenekli öğrencilerin kurguladığı yaratıcı yazma çalışmalarında 'deus ex machina' unsurları" konusunda, herhangi bir çalışma tespit edilememiştir. "Özel yetenekli öğrenci", "yaratıcı yazma", "deus ex machina" anahtar kelimelerini bir araya getiren ve özel yetenekli öğrencilerin kurguladığı yaratıcı yazma çalışmalarındaki "deus ex machina" unsurlarını ortaya çıkarmayı çalışan araştırma, bu yönü ile özgünlük göstermektedir.

Bu çalışma özel yetenekli öğrencilerin normal gelişim gösteren akranlarına göre daha yaratıcı yazılar yazabilecekleri varsayımına dayanmaktadır. Çalışmanın özel yetenekli bireyler örnekleminde ve yaratıcı yazma alanında yapılmış olması nedeniyle hem özel yetenekli bireylerin eğitimi hem de yazma becerisi eğitimi alanına katkı sunması beklenmektedir. 
Bilimsel araştırmalarda sınırılıkların açık ve net bir şekilde ifade edilmesi bulguların geçerli ve güvenilir olması için hayatî önem taşımaktadır. Bundan dolayı bu çalışma;

a) 2019-2020 Eğitim ve Öğretim Yılı ile

b) Örnekleme dâhil edilen kırk iki özel yetenekli öğrenci ile

c) Çalışmada kullanılan etkinlik ile

d) Etkinliğin uygulandığı üç ders saati ile sınırlandırılmıştır.

Sınırlııklar, gelecekteki benzer çalışmalara yol göstermeye, bilimsel dürüstlüğün gereğini yerine getirmeye, okuyucularda eleştirel düşünceyi geliştirmeye, okuyucu ve yazar arasında güven ilişkisini kurmaya önemli ölçüde katkı sağlayacaktır (Özkan \& Kaya, 2015). Ayrıca, sınırlııkların yazarlar tarafından bilinmesi, kabul edilmesi ve tarafsızca tartışılması, makalenin bilimsel niteliğe sahip olması açısından önem arz etmektedir.

\section{Araştırmanın Modeli}

\section{Yöntem}

Özel yetenekli öğrencilerin kurguladığı yaratıcı yazma çalışmalarındaki "deus ex machina" unsurlarını ortaya çıkartmayı amaçlayan bu çalışma, nitel araştırma yöntemlerinden doküman analizi ekseninde planlanmış ve gerçekleştirilmiştir. Doküman analizi, araştırılması hedeflenen olgu veya olgular hakkında bilgi içeren yazılı dokümanların analizini kapsamaktadır (Yıldırım \& Şimşek, 2008). Doküman analizinde, mevcut kayıt ya da belgelerin, veri kaynağı olarak sistemli incelenmesi yapılır. Başarılı bir doküman analizinin temel şartı, konuya ilişkin belgelerin bulunması, incelenmesi ve belli durum ya da görüşleri ortaya çıkartacak bir senteze varılabilmesi için gerekli düzenlemelerin yapılabilmesidir (Karasar, 2010). Araştırma kapsamında analiz edilen yazılı dokümanlar kırk iki özel yetenekli öğrencinin kaleme aldığı kırk iki yaratıcı yazma örneğidir. Bu yaratıcı yazıların tamamı özgün, gerçek ve birinci elden kaynaklardır. Bu öğrencilere ait yaratıcı yazılar birbirinden bağımsız üç uzman tarafından analiz edilmiş, ilgili kodlamalar yapılmış, kategoriler belirlenmiş ve "deus ex machina" temasına ulaşılmıştır.

\section{Araştırma Grubu}

Çalışmanın araştırma grubunu kırk iki özel yetenekli 4. sınıf öğrencisi oluşturmaktadır. Bu öğrenciler "genel zihinsel yetenek" alanında tanılanmış ve zekâ düzeyleri 130 (IQ) ve üzerindeki bireylerdir. Çalışma grubuna dâhil edilen kırk iki (\%100) öğrenciden yirmisi (\%47.6) kız, yirmi ikisi (\%52.4) ise erkektir. Bu öğrenciler arasında sosyo-kültürel bir fark bulunmamaktadır. Öğrencilerin tamamı çalışmaya gönüllü olarak katılmışlardır. Gönüllük esasına dayanan bu çalışma için hem öğrencilerin hem de velîlerin onayladığı "gönüllü katılım belgesi" düzenlenmiştir. Çalışmaya başlamadan önce çalışmanın amacı ve önemi hakkında öğrenciler ve velîler bilgilendirilmiştir.

\section{Veri Toplama Süreci}

Çalışma verileri haftada bir ders saati olmak üzere üç hafta süre ile uygulanan bir yaratıcı yazma etkinliği ile toplanmıştır. Etkinlik hem çizme ve boyama hem de yazma becerilerini bünyesinde bulundurmakta olan disiplinler arası bir etkinliktir. Bayındır'a (2013) göre çocuğun farklı renk kalemler kullanarak farklı çizgiler çizmesi, bu çizgileri farklı bütünler hâline getirmesi, oluşturduğu kompozisyonu yazarak anlatması yaratıcı yazmaya örnektir. Öztürk (2007) ise yaratıcı yazma çalışmalarında resim kullanılmasının teşvik edilmesi gerektiğini belirtmiştir.

Etkinliğin ilk haftasında, bir ders saati süresince ilk uygulama yapılmıştır. Bu uygulamada üzerinde birbiriyle ilişkilendirilmemiş geometrik şekillerin bulunduğu A4 boyutundaki kâğıtlar öğrencilere dağıtılmıştır. Öğrencilerden, şekilleri yorumlayarak değiştirerek veya düzenleyerek bir resim çizmeleri istenmiştir. Bu esnada öğrencilere herhangi bir yönlendirme ya da yorum yapılmamıştır. Kâğıdı yatay, dikey ya da çapraz olarak kullanabilecekleri belirtilmiştir. ilggili çalışma kâğıdı aşağıda belirtilmiştir (Şekil. 1). 


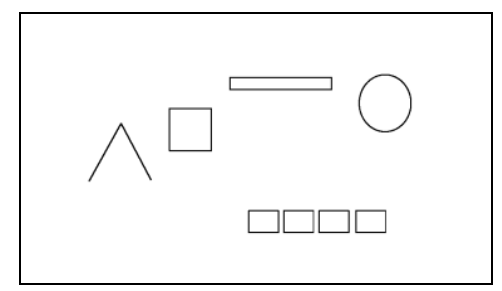

Şekil 1. Çalışma Kâğıdı

Etkinliğin ikinci haftasında, öğrencilere boya verilerek geçen hafta çizdikleri resimleri boyamaları istenmiştir. Boyama işlemi için öğrencilere bir ders saati (40 dk.) süre verilmiş̧ir. Boyama esnasında renk seçimi, kâğıt düzeni, perspektif gibi konularda hiçbir yönlendirme yapılmamıştır. Öğrencilerin boyadıkları resimler hakkında hiçbir yorum yapılmamıştır. Çizilen/boyanan resimlerden birkaç örnek aşağıda belirtilmiştir (Şekil.2).
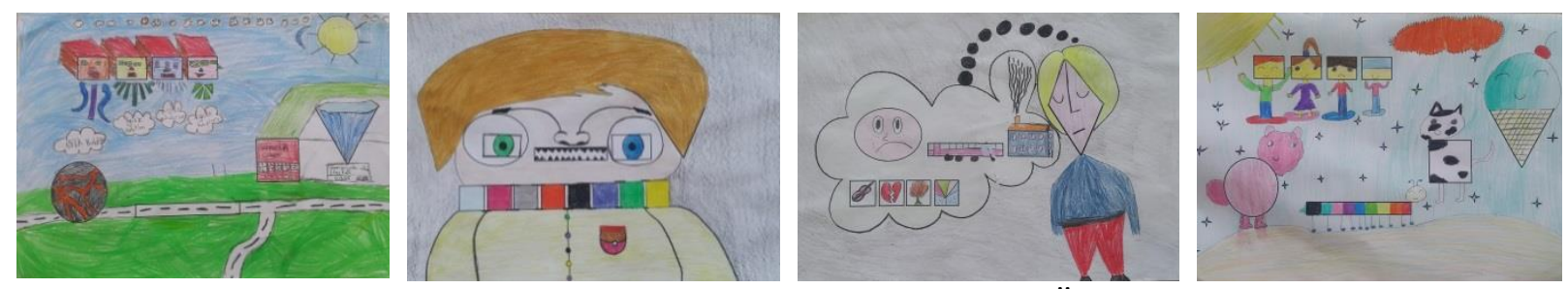

Şekil 2. Çizilen Resimlerden Birkaç Örnek

Etkinliğin üçüncü haftasında ise öğrencilerden, çizdikleri resimlerde ifade etmeye çalıştıkları olay ya da olayları yazmaları istenmiştir. Öğrencilere boş bir A4 kâğıdı ve bir ders saati (40 dk.) süre verilmiştir. Süre sonunda öğrencilerin çizdiği resimler ve yazdıkları yazılar "metin sıra numarasıöğrenci sınıfı-öğrenci cinsiyeti" yazılarak toplanmıştır. Kâğıtlara öğrenci isimleri yazılmamıştır. Örneğin "3-4-E" ile kodlanan metin 3. sıradaki, 4. sınıf, erkek öğrenciye aittir. Ayrıca öğrencilere yazı ve resimlerinin bir hafta sonra iade edileceği belirtilmiştir. Yazılan yazılardan birkaç örnek aşağıda belirtilmiştir (Şekil.3).
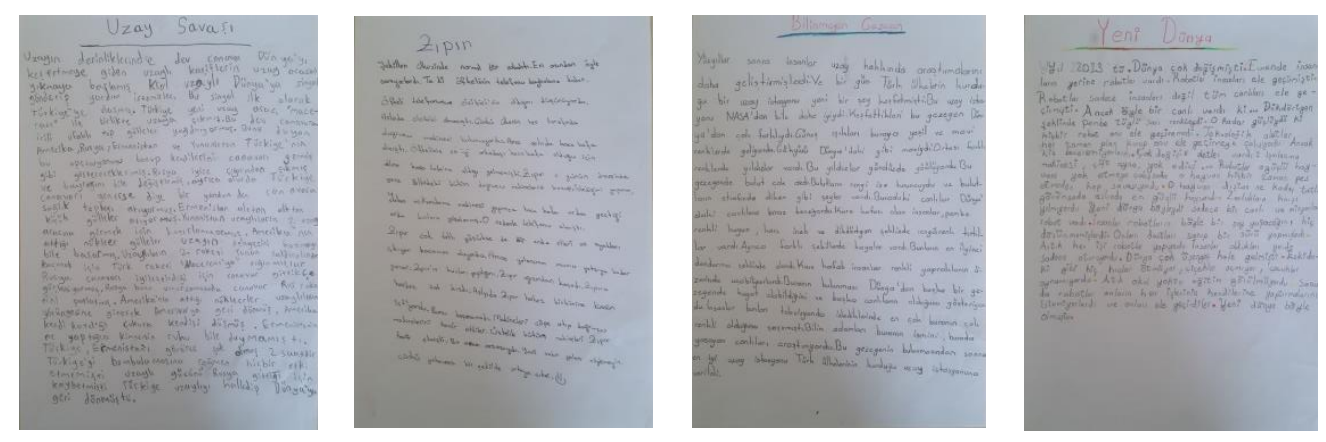

Şekil 3. Yazılan Yazılardan Birkaç Örnek

Birer hafta ara ile $40^{\prime}+40^{\prime}+40^{\prime}$ dakikalık üç ders saatinde tamamlanan çalışma sonucunda kırk iki metne ulaşılmıştır. Tablo.1'de metinlerdeki kelime ve cümle sayıları verilmiştir.

Tablo.1

Katılımcıların Oluşturduğu Metinlerin Kelime ve Cümle Sayıları

\begin{tabular}{cccc}
\hline & En Az & En Çok & Ortalama \\
\hline Cümle & 17 & 39 & 24 \\
\hline Kelime & 72 & 215 & 149 \\
\hline
\end{tabular}


Tablo.1'deki bilgilerden hareketle en kısa metnin on yedi; en uzun metnin ise otuz dokuz cümleden oluştuğu görülmektedir. Ortalama bir metin yirmi dört cümleden oluşmuştur. Metinlerdeki kelime sayılarına bakıldığında ise en kısa metin yetmiş iki; en uzun metin ise iki yüz on beş kelimeden oluştuğu görülmektedir. Bir metindeki ortalama kelime sayısı yüz kırk dokuzdur.

\section{Verilerin Analizi}

Özel yetenekli kırk iki (42) öğrenciden toplanan yazı örnekleri "deus ex machina" kavramı hakkında bilgi sahibi üç uzman tarafından birbirinden bağımsız olarak kodlanmıştır. Uzmanlardan ikisi Türkçe öğretmeni diğeri ise Türk dili ve edebiyatı öğretmenidir. Yazıların üç uzman tarafından kodlanmasının temel amacı güvenirliği sağlamak ve insan kaynaklı okuma hatalarını en aza indirgemektir. Uzmanlara değerlendirmeleri için aynı veri seti fotokopi ile çoğaltılarak verilmiştir. Uzmanların kâğıt üzerinde "deus ex machina" unsurlarını "var" ya da "yok" olarak belirtmeleri, "var" ise ilgili cümlenin ya da cümlelerin altının çizilmesi istenmiştir. Bu işlemin daha disiplinli ve dengeli bir şekilde yapılabilmesi için üç ölçüt soru belirlenmiştir. Bu ölçütleri tam olarak karşılayan kurgu hatalarının "deus ex machina" olarak belirlenmesi kararlaştııılmıştır. Birinci ölçüt soru: "Deus ex machine, kurguya ters bir şekilde olayı sonlandırmış mıdır?" sorusudur. íkinci ölçüt soru: "Deus ex machina, ani ve beklenmedik bir şekilde ortaya çıkmış mıdır?" sorusudur. Son ölçüt soru ise "Deus ex machina, metnin sonunda mıdır?" sorusudur. Her bir kodlayıcı, yazıları birbirinden bağımsız olarak okumuş ve bu üç ölçüte göre kodlama yapmıştır. Böylece farklı kodlayıcılar tarafından aynı veri setinin kodlanması sağlanmıştır. Genel bir kural olarak farklı kodlayıcılar tarafından kodlanan veri setinin benzerlik oranı önemlidir (Fidan \& Öztürk, 2015). Bu benzerlik oranı aynı zamanda nitel araştırmanın güvenirliğini belirlemektedir (Baltacı, 2017). Miles ve Huberman (1994) modelinde içsel tutarlılık olarak adlandırılan ve kodlayıcılar arasındaki görüş birliği olarak kavramsallaştırılan bu benzerlik, $\Delta=C \div(C+\partial) \times 100$ formülü kullanılarak hesaplanmaktadır. Formülde, $\Delta$ : kodlayıcılar arası güvenirlik katsayısını, C: üzerinde görüş birliği sağlanan konu/terim sayısını, d:üzerinde görüş birliği bulunmayan konu/terim sayısını ifade etmektedir. İçsel tutarlılı̆ı veren kodlama denetimine göre kodlayıcılar arası görüş birliğinin en az \%80 olması beklenmektedir (Miles \& Huberman, 1994; Patton, 2002). Okuma sonucunda kodlayıcılar arası güvenirlik, Miles ve Huberman (1994) formülüne göre (Kodlayıcılar Arası Güvenirlik=16 $\div(16+2) \times 100) \% 88,8$ olarak tespit edilmiştir. Bu sonuçtan hareketle kodlayıcılar arasında görüş birliğinin sağlandığı anlaşılmıştır. Bir kodlama örneği aşağıda verilmiştir.

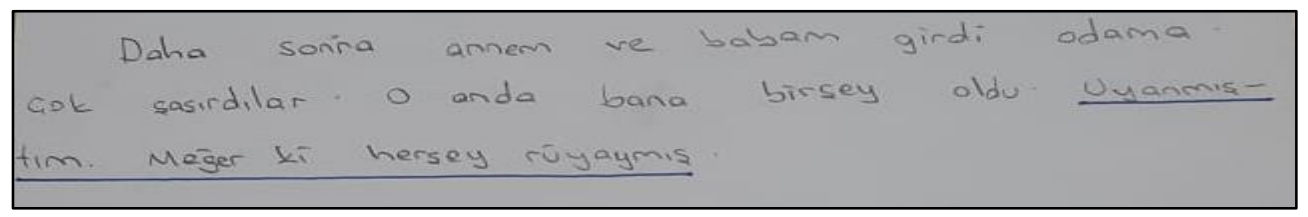

Şekil 4. Bir Kodlayıcı Tarafından Yapılan Kodlama Örneği

Şekil.4'te yer alan "deus ex machina” unsuru metin kurgusuna tamamen terstir. Çünkü uzaydaki bir savaşı anlatan metin, sonuca ulaşmadan yazarın uykudan uyanmasıyla sona ermiştir. Metindeki "deus ex machina" ani ve beklenmedik bir şekilde ortaya çıkmıştır. Uzaydaki savaş devam ederken yazarın odasına anne ve babası girmiş, yazar uykudan uyanmıştır. "Deus ex machina" metnin sonunda ortaya çıkmıştır. Bu "deus ex machina" örneğini içeren metin; 23. sıradaki, 4. sınıfta öğrenim gören, bir erkek öğrenci tarafından yazıımıştır (23-4-E).

\section{Birinci Alt Probleme ilişkin Bulgular}

\section{Bulgular}

Araştırmanın birinci alt problemini "Özel yetenekli öğrenciler kurguladıkları yaratıcı yazma çalışmalarında 'deus ex machina' unsurlarına yer vermekte midir?" sorusu oluşturmaktadır. Şekil.5'te elde edilen bulgular grafiksel olarak ifade edilmiştir. 


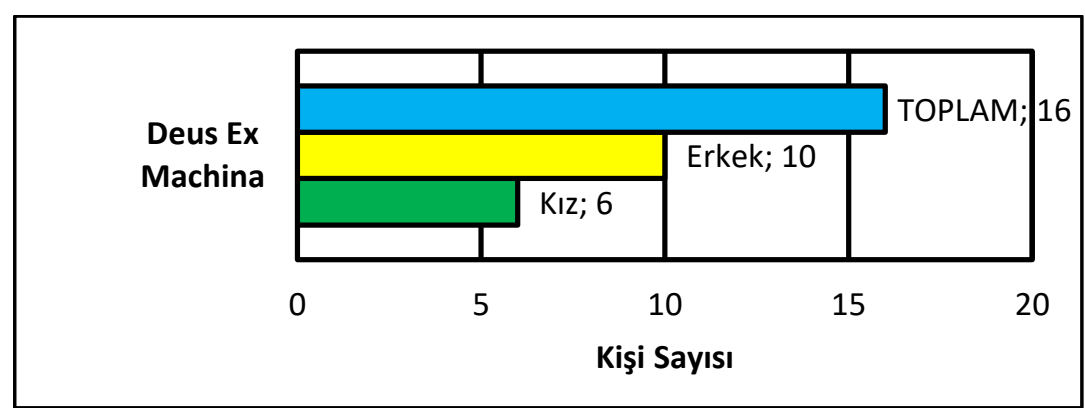

Şekil 5. "Deus Ex Machina” Unsurlarının Sayısal Dağılımını Gösterir Grafik

Özel yetenekli kırk iki öğrenci tarafından oluşturulan kırk iki (\%100) yaratıcı yazma örneği, içerisinde beklenmedik ve kurguya uymayan ani bir son olarak adlandırılan "deus ex machina" unsuruna göre incelendiğinde on altı (\%38) metinde bu unsura yer verildiği görülmüştür. Bu, on altı (\%100) "deus ex machina" unsurundan on (\%62.5) "deus ex machina" unsurunun özel yetenekli erkek öğrencilere ait olduğu, geriye kalan altı (\%37.5) "deus ex machina" unsurunun ise özel yetenekli kız öğrencilere ait olduğu görülmüştür. Bu verilerden hareketle özel yetenekli erkek öğrencilerin, kız öğrencilere göre daha fazla kurgu hatası yaptığı ve "deus ex machina"ya başvurduğu görülmüştür.

\section{İkinci Alt Probleme ilişskin Bulgular}

Araştırmanın ikinci alt problemini "Özel yetenekli öğrencilerin kurguladığı yaratıcı yazma çalışmalarında yer alan 'deus ex machina' unsurları hangi varlık ya da şahıs ile sembolize edilmiştir?" sorusu oluşturmaktadır. Katılımcılardan on altı özel yetenekli öğrenci, birinci alt problemde de görüleceği üzere, "deus ex machina" unsuruna yer vermiştir. Bu öğrenciler genele oranla \%38'lik dilimi temsil etmektedir. Burada değinilen on altı metin içerisindeki "deus ex machina" unsurlarının kurguya yansıma şekillerinde ise semboller birbirinden farklı olmuştur. Bu sembollerin her biri benzer kodların oluşturduğu bir kategoridir. Bu kategorilerin grafiksel ifadesi aşağıda yer almaktadır (Şekil.6).

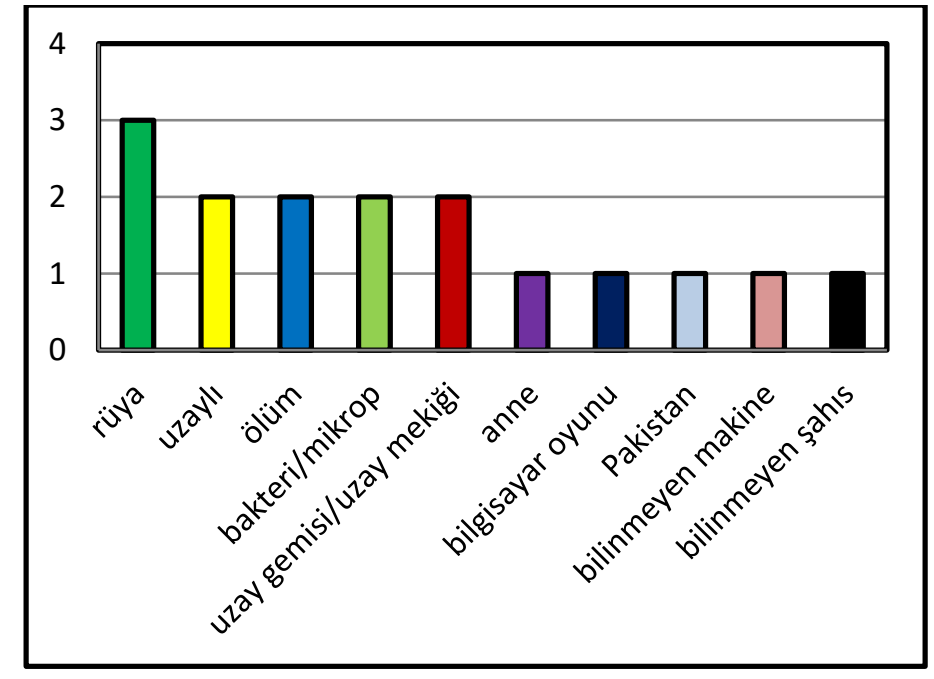

Şekil 6. "Deus Ex Machina” Unsurlarının Sembolize Ediliş Biçimlerini Gösterir Grafik

Şekil.6'daki grafik incelendiğinde en çok tercih edilen "deus ex machina" sembol unsurunun rüya olduğu görülmektedir. Bunu uzaylı, ölüm, bakteri/mikrop, uzay gemisi/uzay mekiği takip etmektedir. Bilinmeyen makine, anne, bilgisayar oyunu, Pakistan, bilinmeyen şahıs unsuruna ise bir kere yer verilmiştir.

Şekil.6'da yer alan analiz sonucunda tespit edilen "deus ex machina" unsuru içeren cümleler doğrudan alıntı ile aşağıda belirtilmiştir. Alıntı sonunda parantez içinde yer alan sayılardan birincisi metin numarasını, ikincisi sınıf düzeyini, harf ise öğrenci cinsiyetini belirtmektedir. Şekil.6 
incelendiğinde en çok tercih edilen sembol unsurunun "rüya" olduğu görülmektedir. Rüya unsuruna yer veren "deus ex machina" örnekleri aşağıda verilmiştir.

"...Daha sonra annem ve babam girdi odama. Çok şaşırdılar. $\mathrm{O}$ anda bana bir şey oldu. Uyanmıştım. Meğerki her şey bir rüyaymış." (23-4-E)

"...Uyandığımda etrafımda hiç kimse yoktu. Çok terlediğimi fark ettim. İyi ki gördüklerim gerçek değildi." (7-4-E)

"...Gözlerimi açtığımda kendimi uzay boşluğunda hissettim. Yataktan düşmüştüm. Böyle rüyalara halk arasında karabasan diyorlardı." (11-4-E)

Yukarıda belirtilen üç "deus ex machina" unsurunda da kahraman ani ve beklenmedik bir şekilde uykudan uyanmış ve bunun sonucunda olay çözüme ulaşmadan sona ermiştir. İncelenen metinlerde karşımıza çıkan bir diğer "deus ex machina" unsuru ise uzaylıdır. Uzaylı unsuruna yer veren "deus ex machina" örnekleri aşağıda verilmiştir.

“...Çok güçlü bir orduya sahip olan Amerikalılar uzaylılarla savaşıyordu. Ama hesaba katmadıkları bir şey vardı. Aniden dev bir uzaylı ortaya çıkmıştı. Ve uzaylılar ortaya çıkan dev uzaylı sayesinde galip gelmişlerdi. Artık, Dünya'nın sahibi uzaylılardı." (35-4-E)

Yukarıda belirtilen "deus ex machina" unsurunda "aniden" ortaya çıkan dev uzaylının kurguyu beklenmedik bir şekilde sonlandırdığı görülmektedir. Bir diğer uzaylı unsuruna yer veren "deus ex machina" örneği ise aşağıda belirtilmiştir.

“...Pembe tüylü güçlü hayvan tek başına uzaylılarla savaşıyordu. Platinyum gezegeninden gelen kuyrukları ejderhaya benzeyen uzaylılar onu öldürmüşlerdi. Onlar gelmeseydi belki de savaşı pembe tüylü güçlü hayvan kazanacaktı." (15-4-K)

$\mathrm{Bu}$ "deus ex machina" unsurunda ise "Platinyum gezegeninden gelen kuyrukları ejderhaya benzeyen uzaylılar" metin kurgusunu beklenmedik bir şekilde sonlandırmıştır. Platinyun isimli gezegen ve kuyrukları ejderhaya benzeyen uzaylılar metinde daha önce yer almamıştır. Aniden ortaya çıkmışlar ve kurguyu sonlandırmışlardır. Ölüm unsuru ise "deus ex machina" olarak iki metinde karşımıza çıkmıştır.

“...Herkes aniden ölmüştü. Neden böyle olduğunu yazar dahi bilmiyordu."

(39-4-E)

“...Dağ kızı Özge aniden ölmüştü. Yazımız da burada bitti." (41-4-K)

Yukarıdaki iki "deus ex machina" örneğinde de "aniden" sözcüğü yer almaktadır. Ani bir ölüm metin kurgusunu beklenmedik bir şekilde sonlandırmıştır. Bakteri/mikrop unsuru ise iki metinde "deus ex machina" olarak karşımıza çıkmıştır.

"...Astronotlar uzaydan bakteri kapmışlardı. Bu uzay çalışmalarının sonu olmuştu." (6-4-K)

"...Birdenbire yataklara düşmüştü. Hiçbir planını gerçekleştiremeyecekti.

Çünkü on yıl önce kaptığı mikrop şimdi etkisini göstermişti." (37-4-E)

Yukarıda belirtilen iki "deus ex machina" örneğinde de metin içerisinde daha önce bahsedilmeyen bir bakteri ve mikrop ortaya çıkmış, metin kurgusunu beklenmedik bir şekilde sonlandırmıştır. Uzay gemisi ve uzay mekiği ise iki metinde ortaya çıkan ve kurguyu beklenmedik bir şekilde sonlandıran diğer "deus ex machina" örneğidir.

"...Esrarengiz bir uzay gemisi tüm elmasları toplayıp götürdü. Artık savaşmaya gerek yoktu." (34-4-K)

Yukarıda yer alan "deus ex machina" örneğinde, yeryüzündeki elmaslar için birçok ülke mücadele ederken metinde daha önce yer almayan esrarengiz bir uzay gemisinin ortaya çıkması ve bütün elmasları alıp götürmesi ile kurgu beklenmedik bir şekilde sona ermektedir.

“...Bütün olaylar meğerse bir uzay mekiğinin içinde olmuştu. Uzay mekiği gidince her şey bitmişti." (22-4-E)

Uzay mekiği olarak ortaya çıkan ve yukarıda belirtilen "deus ex machina"da ise "meğerse" sözcüğü ile beklenmedik ve bilinmeyen bir unsur anlatılmak için kullanılmıştır. Kurguda anlatılan olayların bir uzay mekiğinde geçtiği hiç kimse tarafından bilinmemektedir. Uzay mekiği aniden gitmiş, 
kurgu sona ermiş fakat olay çözüme kavuşmamıştır. Anne, bilgisayar oyunu, Pakistan, bilinmeyen makine, bilinmeyen şahıs unsurları da birer metinde kurgu hatası olarak ortaya çıkmıştır. Bu "deus ex machina" unsurları aşağıda belirtilmiştir.

"Anne" unsuruna yer veren "deus ex machina" örneğinde, daha önce metnin hiçbir yerinde bulunmayan "anne" unsuru, elinde bir çanta dolusu para ile aniden ortaya çıkmış ve kahramanın problemini çözmüştür.

“...Çok fakir oldukları için protez bacaklara kavuşması imkânsızdı. Akşam annesi eve bir çanta dolusu para getirmişti. Artık protez bacakları alabilecekti." (33-4-K)

"Anne" bir çanta dolusu parayı nasıl elde etmiştir? Metnin hiçbir yerinde olmayan "anne" unsuru neden beklenmedik bir şekilde metnin sonunda ortaya çıkmıştır? Bu çözüm metin tutarılı̆̆ını sekteye uğratmıştır.

"Bilgisayar oyunu" unsuruna yer veren "deus ex machina" örneğinde ise tüm kurgunun bir anda bitmesi söz konusudur. Metnin başında, olayların bir bilgisayar oyunu içerisinde geçtiği ile ilgili hiçbir bilgi bulunmamaktadır. Yazar her şeyin bir bilgisayar oyunu olduğunu söyleyerek kurguyu aniden bitirmiş ve metin içerisindeki düğümü çözmemiştir.

"...Her şey bir bilgisayar oyunundan ibaretti." (40-4-E)

"Pakistan" unsuruna yer veren "deus ex machina" örneğinin bulunduğu metinde ise uzayda devam eden ve birçok ülkenin dâhil olduğu bir savaş konu edinmiştir. Pakistan bu ülkelerden biri değildir. Fakat birdenbire metnin sonunda ortaya çıkmakta ve yenilmekte olan Türkiye'yi kurtarmaktadır.

“...Uzayda savaş devam ediyordu. Rusya, Amerika ve Ermenistan, Türkiye’ye

saldırıyordu. Türkiye yenilecekti. Tam bu esnada Pakistan ortaya çıktı. 240

milyon dolarlık bir yardımla Türkiye'yi ayağa kaldırdı." (17-4-E)

"Bilinmeyen makine" unsuruna yer veren "deus ex machina" örneğinde ise metinde daha önce yer almayan bir makine ansızın ortaya çıkmıştır. Bu makinenin patates enerjisiyle çalışması da anlam verilemeyen bir diğer soru işaretidir. Çünkü kurguda ne bir makineden ne de patateslerden bahsedilmektedir.

"...Biiiipppp diye bir ses duyuldu. Patates enerjisiyle çalışan makinenin patatesleri bitmişti." (2-4-E)

"Bilinmeyen şahıs" unsuruna yer veren "deus ex machina" örneğinin olduğu metinde ise çözülemeyen bir matematik problemini çözmeye çalışan insanlar konu edinmiştir. İnsanlar türlü yollara başvurmakta fakat soruyu çözememektedirler. Soruyu çözmek için insanlar bir yarış hâlindedirler. Fakat metnin şahıs/varlık kadrosuyla ilişkilendirilemeyen, bilinmeyen bir kişi "birdenbire" ortaya çıkmış ve tüm soruları çözmüştür.

“...Birdenbire ortaya çıkan bilinmeyen bir kişi bütün matematik sorularını çözmüştü. Artık yarışa gerek yoktu." (34-4-K)

On altı "deus ex machina" unsuru değerlendirildiğinde üçünde "aniden", ikisinde "birdenbire", birinde ise "meğerse" kelimeleri ani ve beklenmedik bir sonun habercisi niteliğindedir. Geriye kalan on "deus ex machina" örneğinde ise bu gibi kelimeler yer almamasına rağmen beklenmedik ve ani bir son bulunmaktadır. Burada verilen araştırma bulgularından hareketle bazı sonuçlara ulaşılmış ve sonuçlardan hareketle bazı önerilerde bulunulmuştur.

\section{Sonuç, Tartışma ve Öneriler}

Özel yetenekli öğrencilerin kurguladığı yaratıcı yazma çalışmalarındaki "deus ex machina” unsurlarını ortaya çıkartmayı amaçlayan bu çalışma verilerine göre kırk iki özel yetenekli öğrenciden on altısının (\%38) yazılarında ani, çelişkili ve beklenmedik bir çözüm olarak nitelendirilen ve bir kurgu hatası olarak değerlendirilen "deus ex machina"ya başvurduğu ortaya çıkmıştır. On altı öğrenciden altısı kız, onu ise erkektir. On altı "deus ex machina" unsurunun rüya, ölüm, bakteri, uzaylı, bilinmeyen makine, anne, bilgisayar oyunu, Pakistan, uzay gemisi/uzay mekiği, bilinmeyen şahıs gibi çeşitli kategorilere ayrıldığı görülmüştür. En çok tekrar edilen "deus ex machina" unsurunun "rüya" olduğu tespit edilmiştir. Uysal'ın (2017) üniversite öğrencileriyle yapmış olduğu "Türkçe Öğretmeni 
Adaylarının Kurgu Becerileri ve 'Deux Ex Machina' Üzerine Bir Değerlendirme” isimli çalışmada da "rüya, hayal ve sanrı" unsurlarının en çok başvurulan "deus ex machina" unsuru olduğu tespit edilmiştir. Bu yönüyle çalışma bulguları benzerlik göstermektedir. Ayrıca Uysal'ın (2017) yapmış olduğu çalışmada, Türkçe öğretmeni adayları tarafından istasyon tekniği kullanılarak üretilen otuz yaratıcı yazıdan yirmi birinde (\%70) "deus ex machina” unsuruna yer verdiği görülmüştür. Kırk iki özel yetenekli dördüncü sınıf öğrencisi örnekleminde yapılan bu çalışmada ise kırk iki yaratıcı yazıdan on altısında (\%38) "deus ex machina" unsuru olduğu tespit edilmiştir. İki çalışma arasında yazma tekniği ve örneklem açısından belirgin farklar bulunmakla beraber, üniversite öğrencilerinin istasyon tekniği kullanarak yazdıkları yazılarda, özel yetenekli öğrencilerin bireysel yazılarına nazaran daha fazla "deus ex machina" unsuru olduğu görülmektedir.

"Deus ex machina" metin tutarlılı̆ını sekteye uğratan bir unsurdur. Tutarlılık ise metin içindeki anlamsal ve mantıksal bağlantılarla oluşan, konu akışındaki bütünlüktür (Coşkun, 2005). Subaşı Uzun'un (2015) da belirttiği gibi metin tutarlıı̆ını başta anlatılanla sonda söylenen arasındaki bütünlük ile ele alınan konunun sürekliliği ve ilgililiği sağlar. Kısaca, metin kendi içinde ne şekilde olursa olsun çelişki taşımaz. Can (2012) ise bir yazının basit bir cümleler dizisi olmaktan çıkıp metin hâline gelebilmesi için metinde sözü edilen konunun bir sona, bir sonuca doğru ilerlemesi ve gelişmesi gerektiğini belirtmiştir. Ayrıca metin içerisinde birbiriyle çelişen fikirlerin bir arada bulunmaması gerektiğini ve metne konu olan göndergelerin, dış dünya gerçekleriyle örtüşmesi, bunlarla belli bir bağlantı içinde olması gerektiğini vurgulamıştır. Oysa "deus ex machina" kurguya ters, beklenmedik, ani bir şekilde olayın sona ermesidir. "Deus ex machina" gibi metin tutarlılığını bozan kurgu hatalarını engellemenin yolu ise kurallı ve sistemli bir yazma eğitiminden geçmektedir. Birçok araştırmacıya göre yazma çalışmalarında başarılı olmak, sıkı ve zorlu bir yazma süreci ve yıllar süren uygulamalar gerektirmektedir (Collins \& Parkhurst, 1996; Collins \& Cross, 1993; Ganopole, 1988; Applebee, Langer \& Mullis, 1986). Öğrenciler, temel dil becerileri içinde en çok yazmada zorlanmaktadırlar (Baş \& Şahin, 2013). Çünkü yazma becerisini mekanik bir süreç olarak değil eleştirel bir düşünme süreci olarak algılamak ve bilmek gerekmektedir (Demirel, 1996). Çok yaratıcı bir sanatçı olan W. A. Mozart ilk eserini bestelediğinde 19 yaşında olmasına rağmen, 3 yaşından beri babasından müzik eğitimi aldığı bir gerçektir. Çünkü tüm yaratıcılık kuramlarında benzer şekilde olduğu gibi alt yapısı bulunmayan bir alanda yaratıcı ürün ortaya koymak mümkün değildir (Karabey \& Yürümezoğlu, 2015). Üstün zekâ ve yaratıcılık arasında bir ilişki olmadığı, çeşitli çalışmalarla ortaya konmuş olmakla birlikte (Barron, 1969; MacKinnon, 1978) üstün/özel yetenekli bireylerden daha yaratıcı ürünler ortaya koyması beklenmektedir. Tezcan (1987) ise Türkiye'deki okulların daha çok zihinsel gelişmeye önem veren, sosyal gelişmeyi ihmal eden, sosyal faaliyetleri kısıtlayan, öğrencilerin yaratıcılıklarını törpüleyen kurumlar olarak eleştirildiğini belirtmektedir. Fakat Türkiye'de 2019 yılında gelindiğinde, özel yetenekli öğrencilerin eğitimi, kendine ait öğretimsel kimliği olan yeni bir disiplin olarak ortaya çıkmış ve Millî Eğitim Bakanlığı (MEB) tarafından “Özel Yetenekliler için Türkçe Öğretim Programı”nın bir taslağı oluşturulmuştur. Böylece özel yetenekli öğrenciler için geliştirilen özel öğretim programlarının genel öğretim programlarından özgün bir şekilde farklılaştııılması hedeflenmiştir. Bununla birlikte genel öğretim programlarının özel yetenekli öğrencilerin eğitiminde çeşitli yönleriyle yetersiz kalması sonucu daha ilk ve ortaokul yıllarında yetenek kayıplarının oluşması, dünya genelinde bu öğrenciler için özel eğitim modellerinin ve özel öğretim programlarının geliştirilmesinin temel gerekçesini oluşturmuştur. Özel yetenekli öğrenciler için geliştirilen standart bir programın bu öğrencilerin gelişim intiyaçlarını karşılamada yeterli olacağı düşüncesi Özel Yetenekliler için Türkçe Dersi Öğretim Programı́nın (2019b) temel hipotezi olarak ortaya çıkmıştır. Bütün bireylerin tam başarısı, sadece kişinin kendi iyiliği için değil; toplumun yararı için de desteklenmelidir. Herkes için en uygun eğitim evrensel bir amaç olmalıdır. Özel yetenekli öğrencilere sunulan zenginleştirilmiş, hızlandırılmış etkinliklere dayalı olarak uygulanan programların amacı seçkin bir grup yetiştirmek ya da bu bireyleri kayırmak değil, özel yetenekli bireylerin sahip oldukları ve geliştirebilecekleri farklı yeteneklerini ortaya çıkarabilmeleri için onlara imkân tanımaktır. Özellikle özel yetenekli, üstün zekâlı, üstün yetenekli olarak adlandırılan bireyler duygusal, sosyal, fiziksel ve zihinsel olarak "eş zamanlı olmayan bir gelişim" sergiledikleri için desteğe intiyaç duymaktadırlar. Türkiye'de ve Dünya'da özel yetenekli öğrencilerin eğitimleri ile ilgili mevcut uygulamaların (gruplama, mentörlük, 
hızlandırma, zenginleştirme) hangisinin daha yararlı olduğu konusu oldukça tartışmalıdır (Çitil \& Ataman, 2018). Fakat özel yetenekli bireylerin yaratıcı özelliklerinin daha güçlü olduğu (Çitil \& Ataman, 2018) yaratıcılığın bastırılabilen, köreltilebilen bir beceri olduğu su götürmez bir gerçektir.

Elde edilmesi zor olan şeylerin daha kıymetli olduğu bir dünyada yaşamaktayız. Bundan dolayı bilgiye ulaşmak kolaylaştıkça bilginin kıymeti azalmıştır. Çünkü bilgi her yerde dağınık bir şekilde bulunmaktadır. Bilgisayarın tuşlarında, yapay zekâya sorduğumuz bir soruda, cep telefonunun ekranında, tabletin görüntüsünde... Bilgi daha kıymetli olduğu dönemlerde zor ulaşılan, zor anlaşılan bir değer görünümündeydi. Bilgiye hükmetme ise insanoğlunun en büyük rüyasıydı. Uysal'ın (2016) da belirttiği gibi 21. yüzyılda roller kısmen değişmiştir. Bilgi, sadece sahip olunması ve peşinden koşulması gereken bir kavram olmaktan çıkıp aynı zamanda üzerine katılarak işlenmesi gereken bir ham madde haline gelmiştir. Bu ham maddeyi işler konuma getirecek olan yeterlilik ise yaratıcılık olarak farklı disiplinler tarafından isimlendirilmiştir. Dildeki yaratıcılı̆ın en somut göstergesi ise yaratıc yazılar yazabilmektir. Yazmayı öğrenmek $1920^{\prime}$ li yılların Türkiye'sinde bir amaç olmuştur fakat 2020 'li yılların Türkiye'sinde bir araçtır. Doğrudan doğruya formel bir eğitimle kazanılan yazma becerisi uygun bir eğitim atmosferinde, sabır, özen ve çaba ile yaratıcı bir hüviyet kazanacaktır. Yazma, kurallı ve sistemli bir eğitim gerektirmektedir. Fakat buradan, Göçer'in (2010) de belirttiği gibi bireylerin duygu ve düşüncelerini bir kalıba sıkıştırma anlaşılmamalıdır. Yazı güzelliği, kâğıt düzeni, dilbilgisi ve yazım kurallarının ilk yıllardan başlayarak okul hayatı boyunca sıkıca tembih edilmesi hatta çoğunlukla çocuğun ne yazdığından daha çok önemsenir olması bir zaman sonra öğrencide yazı yazmayı bir işkence haline getirmektedir (Temizyürek \& Bulut, 2016). Oysaki yaratıcı yazılar, standardı ve biçimi olmayan, özgürce yazılan özgün yazılardır. Fakat özgürce yazmak, kuralsız ve kurgusuz yazmak anlamına gelmemektedir. Yaratıcı yazılar metinsellik ölçütlerinden muaf tutulamaz. Ayrıca yaratıcı yazılardaki kurgu hataları görmezden gelinemez. Kurgu, yaratıcı sürecin sonunda elde edilen ürünlerden birisi olması sebebiyle dil ve edebiyat eğitimiyle doğrudan ilgilidir (Uysal, 2017). Öztürk (2007) iyi bir kurgunun mantıksal uyum içerisinde olması gerektiğini vurgulamıştır. Ayrıca, canavar ve uzay yaratıklarını içeren fantastik ya da bilim kurguya dayalı bütün yazıların çeşitli mantıksal kurallara uyması ve anlamlı olması gerektiğini belirtmiştir. Lin (1998) ise yazmanın, yaratıcılığın bir görünümü olduğu tahminine dayanarak yaratıcılık ve yazı yazma arasında ayrılmaz bir ilişki olduğunu belirtmiştir. Bu nedenle yaratıcı yazı yazma sürecinin, öğrencilerdeki yaratıcılı̆̆ geliştirmenin bir yolu olduğunu söylemek mümkündür. Yaratıcı düşünme ve yazının kesişim noktası olan Türkçe dersi, yaratıcı yazılardaki kurgu hatalarının giderilmesi için büyük bir öneme sahiptir. Türkçe dersinde uygulanan yaratıcı yazma etkinlikleri öğrencilerin yaratıcı bir şekilde dilsel etkileşimde bulunmalarına katkı sağlayacak ve yaratıcılıklarını destekleyecektir.

Özel yetenekli öğrencilerin kurguladığı yaratıcı yazma çalışmalarında "deus ex machina" unsurlarını tespit eden bu çalışma nitel bir araştırma olarak kırk iki özel yetenekli, dördüncü sınıf öğrencisi örnekleminde tasarlanmış ve gerçekleştirilmiştir. Çalışmanın normal gelişim gösteren bireyler örnekleminde de yapılması önerilmektedir. Böyle bir çalışma sayesinde verilerin karşılaştırılması da mümkün olacaktır. Bunun yanı sıra benzer bir çalışmanın özel yetenekli üst sınıf öğrencilerine de uygulanması yaratıcı yazılardaki kurgu hatalarının seyrini daha net bir şekilde görmemizi sağlayacaktır. Yazılarında "deus ex machina" unsuruna yer veren öğrenciler ile bireysel görüşmeler yapılarak "deus ex machina"ya başvurma sebepleri üzerine derinlemesine bir araştırma yapılması da önerilmektedir.

Latince bir kavram olan "deus ex machina"ya Türkçe bir karşılık bulunması ve araştırmacıların bu yabancı terim yerine Türkçe karşıı̆ı̆ı kullanmaları büyük önem taşımaktadır. Bu hassasiyetten dolayı "deus ex machina"ya "sihirli değnek" karşıllı̆ı önerilmektedir. Yazar sihirli bir değnekle yazısına dokunmakta ve böylece olaylar ani ve beklenmedik bir şekilde çözüme kavuşmaktadır. Türkçedeki "sihirli değnek ile dokunmak" deyimi de çözümü mucize bekleyen bir problemi; ani, olağanüstü, mantık dışı ve beklenmedik şekilde çözüme kavuşturan nesne veya nesneleri karşılamak için kullanılmaktadır. 


\section{Kaynaklar}

Abrams, M. H. (1999). A glossary of literary terms. USA: Heinle and Heinle.

Applebee, A. N., Langer, J. A. \& Mullis, I. V. S. (1986). The writing report card: Writing achievement in American schools. Princeton, NJ: Educational Testing Service.

Aristoteles. (2019). Poetika (A. Çokona \& Ö. Aygün, Çev.). İstanbul: İ̧̧ Bankası Kültür Yayınları.

Ataman, A. (2012). Üstün yetenekli çocuk kimdir? Geleceğin mimarı üstün yetenekliler sempozyumu, Namık Kemal Üniversitesi, Tekirdağ.

Baltacı, A. (2017). Nitel Veri Analizinde Miles-Huberman Modeli. Ahi Evran Üniversitesi Sosyal Bilimler Enstitüsü Dergisi , 3 (1) , 1-14.

Barron, F. (1963). Creativity and psychological health. Princeton, NY: Van Nostrand.

Barron, F. (1969). Creative person and creative process. New York: Holt, Rinehart, Winston.

Baş, G. \& Şahin, C. (2013). İlköğretim öğrencilerinin yazma eğilimlerinin farklı değişkenler açısından incelenmesi. Sakarya Üniversitesi Eğitim Fakültesi Dergisi, 3(1), 32-42.

Bayındır, N. (2013). Çocuklarda yaratıcılık ve geliştirilmesi. Ankara: Eğiten Kitap.

Bildiren, A. (2016). Üstün yetenekli çocuklar (3. Baskı). İstanbul: Mega Basın Yayın.

Borland, J. H. (2005). Gifted education without gifted children. In R.J. Sternberg \& J.R. Davidson (Eds.) Conceptions of giftedness (pp. 1-19). USA: Cambridge University Press.

Can, R. (2012). Ortaöğretim öğrencilerinin yazılı anlatımlarında paragraf düzeyinde bağdaşıklık ve tutarlılık, Doktora Tezi, Gazi Üniversitesi, Eğitim Bilimleri Enstitüsü, Ankara.

Clark, B. (2015). Üstün zekâlı olarak büyümek (8. Baskı). (Ogurlu, K., Kaya, F., Çev.). Ankara: Nobel Yayınevi.

Collins, N. D. \& Cross, T. L. (1993). Teaching the writing process to gifted and talented students. Gifted Child Today, 16, 3, 22-23.

Collins, N. D. \& Parkhurst, L. (1996). Teaching strategies for gifted children in the regular classroom. Roeper Review, 18, 277-279.

Conklin, W. \& Frei, S. (2016). Üstün zekâlı ve yetenekliler için eğitim programlarının farklılaştırılması (N. G. Kahveci, Çev.). İstanbul: Özgür Yayıncılık.

Coşkun, E. (2005). Ilköğretim öğrencilerinin öyküleyici anlatımlarında bağdaşıklık, tutarlıık ve metin elementleri, Doktora Tezi, Gazi Üniversitesi Eğitim Bilimleri Enstitüsü, Ankara.

Çitil, M. \& Ataman, A. (2018). Illköğretim Çağındaki Üstün Yetenekli Öğrencilerin Davranışsal Özelliklerinin Eğitim Ortamlarına Yansıması ve Ortaya Çıkabilecek Sorunlar. Gazi Eğitim Fakültesi Dergisi (GEFAD/GUJGEF), 38(1): 185-231.

Davis, G. A. (2013). Üstün yetenekli çocuklar ve eğitimi (M. I. Koç, Çev.). İstanbul: Özgür Yayınevi.

Demirel, Ö. (1996). Türkçe Programı ve öğretimi. Ankara:Şafak Matbaacılık.

Dickens, C. (2014). Oliver Twist (F. D. Abamor, Çev.). İstanbul: İskele Çocuk Yayınları.

Enç, M. (2005). Üstün Beyin Gücü. Ankara: Gündüz Yayıncılık. İlk Baskı: 1973, Üstün Beyin Gücü. Ankara: A.Ü. Eğitim Fakültesi Yayınları.

Fidan, T. \& Öztürk, í. (2015). Perspectives and expectations of union member and non- union member teachers on teacher unions. Eğitim Bilimleri Araştırmaları Dergisi - Journal of Educational Sciences Research, 5 (2), 191-220.

Ganopole, S. J. (1988). Reading and writing for the gifted: $A$ whole language perspective. Roeper Review, 11, 88-91.

Gardner, H. (1993). Frames of Mind: The Theory of Multiple Intelligences. A Subsidiary of Perseus Books, L.L.C. U.S.A. (Tenth-anniversary edition).

Geake, J. \& Dodson, C. (2005). A neuro-psychologial model of the creative intelligence of gifted children, Gifted and Talented International, 20(1).

Getzels, J. W. \& Jackson, P. W. (1962). Creativity and intellgence: explorations with gifted students. New York: Wiley.

Göçer, A. (2010). Türkçe öğretiminde yazma eğitimi. Uluslararası Sosyal Araştırmalar Dergisi The Journal of International Social Research, 3(12), 178-195. 
Hotaman, D. \& Yüksel Şahin, F. (2009). Üstün yetenekli öğrencilerin eğitiminde fırsat eşitliği ile kişisel, eğitsel ve mesleki rehberlik yardımı. The 5th International Balkan Education and Science Congress'de sunulmuş sözlü bildiri, Trakya Üniversitesi, Edirne.

Karabey, B. \& Yürümezoğlu, K. (2015). Yaratıcılık ve üstün yetenekliliğin bazı zekâ kuramları açısından değerlendirilmesi. Dokuz Eylül Üniversitesi Buca Eğitim Fakültesi Dergisi, (40) , 86-107.

Karasar, N. (2010). Bilimsel araştırma yöntemi (21. Baskı). Ankara: Nobel Yayınevi.

Levent, F. (2014). Üstün yetenekli çocukları anlamak. Ankara: Nobel Yayınevi.

Lin, D. (1998). Automatic Retrieval and Clustering of Similar Words, Canada: Montreal.

MacKinnon, D., W. (1978). In search of human effectiveness. Buffalo, NY: Creative Education Foundation.

MEB, (2001). Bilim ve sanat merkezleri yönergesi. Internet'ten 12 Kasım 2019'da http://mevzuat.meb.gov.tr/ dosyalar/523.pdf adresinden alınmıştır.

MEB, (2007). Bilim ve sanat merkezleri yönergesi. Internet'ten 12 Kasım 2019'da http://mevzuat.meb.gov.tr/ dosyalar/524.pdf adresinden alınmıştır.

MEB, (2015). Bilim ve sanat merkezleri yönergesi. İnternet'ten 12 Kasım 2019'da http://mevzuat.meb.gov.tr/ dosyalar/1766.pdf adresinden alınmıştır.

MEB, (2016). Bilim ve sanat merkezleri yönergesi. Internet'ten 12 Kasım 2019'da https://orgm.meb.gov.tr/meb_iys_dosyalar/2016_10/07031350_bilsem_yonergesi.pdf adresinden alınmıştır.

MEB, (2018a). Özel eğitim hizmetleri yönetmeliği. İnternet'ten 20 Kasım 2019'da http://mevzuat.meb.gov.tr/ dosyalar/1963.pdf adresinden alınmıştır.

MEB, (2018b). Güçlü yarınlar için 2023 eğitim vizyonu. Internet'ten 20 Kasım 2019'da http://2023vizyonu.meb.gov.tr/doc/2023_EGITIM_VIZYONU.pdf adresinden alınmıştır.

MEB, (2019a). Türkçe dersi öğretim programı Internet'ten 20 Kasım 2019'da http://mufredat.meb.gov.tr/Dosyalar/20195716392253-02Türkçe\%20Öğretim\%20Programı \%202019.pdf adresinden alınmıştır.

MEB, (2019b). Özel yetenekliler için Türkçe dersi öğretim programı (Taslak). İnternet'ten 03 Mayıs 2019'da"http://mufredat.meb.gov.tr/Programlar.aspx"/TÜRKÇE\%20ÖĞRETIM\%20PROGRAM LARI/Türkçe\%205-8_ÖYÖP_Filigranlı.pdf adresinden alınmıştır.

MEB, (2019c). Bilim ve sanat merkezleri yönergesi. Internet'ten 20 Kasım 2019'da http://tebligler.meb.gov.tr/index.php/tuem-sayilar/viewcategory/87-2019 adresinden alınmıştır.

Miles, M. B. \& Huberman, A. M. (1994). Qualitative data analysis. London: Sage Publication.

Özbay, Y. (2013). Üstün yetenekli çocuklar ve aileleri. Ankara: T.C. Aile ve Sosyal Politikalar Bakanlığı Aile ve Toplum Hizmetleri Genel Müdürlüğü Yayınları.

Özkan, Ö. \& Kaya, Ş. Ş. (2015). Bilimsel makalede "sınırlılıklar" neden ve nasıl yazııı. TAF Preventive Medicine Bulletin. (14) 6.

Öznacar, M. \& Bildiren, A. (2016). Üstün zekâlı ögrrencilerin eğitimi (2. Baskı). Ankara: Anı Yayıncılık.

Öztürk, E. (2007). Yaratıcı yazma gelişim süreci ve ilköğretimde yaratıcı yazı yazma öğretimi. SAÜ, Eğitim Fakültesi Dergisi, 14, 266-273.

Patton, M. Q. (2002). Qualitative research and evaluation methods (3rd Ed.). London: Sage Publications, Inc.

Renzulli, J. S. (1976). The enrichment triad model: A guide for developing defensible programs for the gifted and talented. Gifted Child Quarterly, 20(3), 303-306.

Renzulli, J. S. (1978). What makes giftedness? Reexamining a definition. Phi Delta Kappan, 60, 180184.

Renzulli, J. S. (1992). A general theory for the development of creative productivity through the pursuit of Ideal acts of learning. Gifted Child Quarterly, Vol. 36, pp. 170-82.

Renzulli, J. S. (2005). The three-ring conception of giftedness: A developmental model for promoting creative productivity. In R. J. Sternberg \& J. E. Davidson (Eds.), Conception of giftedness (2nd ed., pp. 266-279). New York: Cambridge University Press. 
Robinson, A., Shore, B. M. \& Enersen, D. L. (2014). Üstün zekâlılar eğitiminde en iyi uygulamalar (Ogurlu, K., Kaya, F., Çev.). Ankara: Nobel Yayınevi.

Rowe, A. J. (2007). Yaratıcı zekâ (Ş. Gürman, Çev.). İstanbul: Prestij Yayınları.

Sak, U. (2016a).Üstün zekâlılar (5. Baskı). Ankara: Vize Yayıncılık.

Sak, U. (2016b). Yaratıcılık gelişimi ve eğitimi. Ankara: Vize Yayıncılık.

Sezgin, B. (2009). Avrupa'da rejisörlük kavramının ortaya çıkışı- "Stanislavski ve Brecht" örnekleri üzerinden yönetmenlik metodolojisinin incelenmesi. Yüksek Lisans Tezi. İstanbul Kültür Üniversitesi, İstanbul.

Stenberg, R. \& Grigorenko, E. L. (2011). Explorations in giftedness. New york, Cambridge University Press.

Subaşı Uzun, L. (1990). Türkçede bazı metin dilbilimsel görünümler üzerine, içinde (yay. haz.: A. S. Özsoy \& H. Sebüktekin) IV. Dilbilim Kurultayı Bildirileri, 71-80, İstanbul: Boğaziçi Üniversitesi Yayınevi.

Şener, S. (2006). Dünden bugüne tiyatro düşüncesi. Ankara: Dost Kitabevi.

Taner, H., And, M. \& Nutku, Ö. (1966). Tiyatro terimleri sözlügü. Ankara: TDK Yayınları.

Temizkan, M. (2010). Türkçe öğretiminde yaratıcı yazma becerilerinin geliştirilmesi. Türklük Bilimi Araştırmaları, (27) , 621-643.

Temizyürek, F. \& Bulut, K. (2016). Çocuğun dil gelişiminde yaratıcı yazmanın önemi. YYü Eğitim Fakültesi Dergisi (YYU Journal Of Education Faculty), Cilt:XIII, Sayı:I,146-163.

Tezcan, M. (1987). Eğitim Sosyolojisi (Editör: A. Hakan). Eskişehir: Açıköğretim Fakültesi Yayınları.

Torrance, E., P. (1962). Guiding creative talent. Englewood Cliffs, NJ: Prentice-Hall.

Torrance, E., P. (1986). Teaching create and gifted learners. In M. C. Wittrock (Ed.), Handbook of research on teaching. New York: MacMillan.

Uysal, B. \& Fincan, A. (2016). Kutadgu Bilig'de yaratıcılık ve yaratma algısı üzerine. Türk ve islam Dünyası Sosyal Araştırmalar Dergisi. 3/8, 97-108.

Uysal, B. (2016). Türkçe eğitiminde algı (Editör: G. Aytaş). Ankara: Akçağ Yayıncılık.

Uysal, B. (2017). Türkçe öğretmeni adaylarının kurgu becerileri ve deus ex machına üzerine bir değerlendirme. I. Uluslararası Türklerin Dünyası Sosyal Bilimler Sempozyumu, Antalya.

Yıldııı, A. \& Şimşek, H. (2008). Sosyal bilimlerde nitel araştırma yöntemleri (6. Baskı). Ankara: Seçkin Yayınları.

Zweig, S. (1949). Yaratıcılığın sırrı (M. Özgü, Çev.). İstanbul: Remzi Kitabevi.

\section{Extended Abstract}

\section{Introduction}

In Turkey improving students' listening, speaking, reading, and writing skills in a systematic and regular manner is expected from Turkish courses. Among these skills, writing is the last acquired language skill. Writing requires formal education because it includes cognitive, affective, and psychomotor skills. Creative writing which is the intersection of creative thinking and writing skills has a different place in writing exercises because it emphasizes originality, freedom, and imagination rather than accuracy or standardization in thoughts. However, creative writing exercises which emphasize originality, freedom and imagination do not exclude textual elements (cohesion, coherence, intentionality, acceptability, informativity, situationally, intertextuality). In creative writing, it is the author who creates the fiction and sets the rules. But the author sometimes overturns the fiction and breaks the rules he sets himself. At a point where events are tied, a person, an object, a machine pushing the limits of logic emerges and solves the events as a god. This fiction error is called as "deus ex machina". In the light of this information, the aim of the research is to reveal the elements of "deus ex machina" in creative writing works of gifted students.

\section{Method}

Document analysis which is one of the qualitative research methods is administered on the data. Document analysis involves the analysis of written documents containing information about the phenomenon or facts that are targeted to be investigated (Yıldırım \& Şimşek, 2005). In document 
analysis, existing records or documents are examined systematically as data source. The basic condition of a successful document analysis is to find necessary documents, to analyse and to make necessary arrangements to reach a synthesis that will reveal certain situations or opinions (Karasar, 2010). Written documents analysed within the scope of the research include forty-two creative writing examples written by forty-two gifted students. These creative writing works are original and first-hand sources. The creative writings of these students were analysed by three independent experts, then data analyses were administered, and a synthesis was made.

\section{Result and Discussion}

Findings of the study indicated that "deus ex machina" was found in sixteen (38\%) of fortytwo $(100 \%)$ creative writing samples. These elements varied as dream, unknown machine, alien, death, bacteria/microbe, mother, computer game, Pakistan, spaceship/space shuttle, unknown person. It was determined that the mostly occurred "deus ex machina" element was "dream". Creative writings are freely written original writings that do not have a standard or form. But to write freely does not mean to write without rules and fiction. Creative writings do not exclude textual criteria. Editing is directly related to language and literature education as it is one of the products obtained at the end of a creative process (Uysal, 2017). Lin (1998) stated that writing is an inseparable relationship between creativity and writing based on the assumption that writing is an appearance of the creativity. Therefore, it is possible to say that the creative writing process is a way to develop creativity among students. Turkish lesson which is the intersection of creative thinking and writing has a great importance for eliminating fiction mistakes in creative writing. Creative writing activities implemented in the Turkish lesson will contribute to students' linguistic interaction creatively and support their creativity. "Deus ex machina" is an element that disrupts text consistency. Consistency is the integrity in the subject flow, which is formed by semantic and logical connections in the text (Coşkun, 2005). Can (2012) stated that in order for an article to become a text rather than a simple set of sentences, the subject mentioned in the text should proceed and develop to an end, a result. However, "deus ex machina" is contrary to fiction, an unexpected and a sudden end of an event. The way to prevent editing errors such as "deus ex machina", which disrupts text consistency, is through regular and systematic writing training. According to many researchers, success in writing studies requires a tight and difficult writing process and years of practice (Collins \& Parkhurst, 1996; Collins \& Cross, 1993; Ganopole, 1988; Applebee, Langer \& Mullis, 1986). Because it is necessary to perceive and know writing skill not as a mechanical process but as a critical thinking process (Demirel, 1996). It is also suggested that the study be carried out in the sample of individuals with normal development so that it will be possible to compare the results. In addition, the application of a similar study to older gifted students will enable us to see the course of editing errors in creative writings more clearly. It is also recommended to conduct an in-depth study on underlying reasons for applying "deus ex machina" by conducting individual interviews with students who include the "deus ex machina" element in their writings. The study is expected contribute both to gifted individuals' education and to the field of teaching writing skills. 